\title{
AN EVALUATION OF INTELLIGIBILITY OF FUNCTIONAL DESCRIPTIONS AND AN ANALYSIS OF THE RHETORICAL ATTRIBUTES FOR ELDERLY PEOPLE
}

\author{
Masayuki SAKAI*, Rena TERUI*, Masae TAGA* and Katsuo INOUE** \\ * Sapporo City University, Geijyutsu-no-mori 1, Minami-ku, Sapporo, Hokkaido, 005-0864, Japan \\ ** Hiroshima International University, 555-36 Kurose-Gakuendai, Higashi Hiroshima, Hiroshima, 739-2695, Japan
}

\begin{abstract}
This study is aimed at improving the user-friendliness of home appliances that support the elderly and other users in their daily lives, by focusing on the functional descriptions appearing on the operation panels of products, as these are considered to have a significant impact on this objective. We also conducted a survey and analysis to assess the intelligibility of these descriptions.

First, we attempted to construct a structural classification to understand the historical changes in descriptive interfaces, giving consideration to a mental model of elderly users. For this, we created an improved method of classifying user interfaces according to whether they are procedure-oriented or aim-oriented, focusing on functional descriptions. When we classified the functional descriptions of current home appliances using this method, we found that an increasing proportion of appliances feature aim-oriented interfaces characterized by qualitative expressions that tend to be vague, making use difficult for elderly people. We thus conducted a survey of interface intelligibility among elderly test subjects, focusing on aim-oriented functional descriptions of washing machines. At the same time, we attempted to classify descriptions according to the expressive forms of figures of speech and semantic modification relations, focusing on the rhetorical aspects of functional descriptions. In addition, we attempted comprehensive classifications according to criteria such as commonality of terms, presence/absence of foreign words. We then explored the relevance to the results of our intelligibility survey of elderly and young subjects.

Our results suggested that some figures of speech and commonality of descriptions may have an impact on the ease-of-understanding of appliance interfaces.
\end{abstract}

Keywords : User Interface Design, Universal Design, Terminology, Rhetoric, Home Appliances

\section{1. は じめに}

高齢化率の伸びが顕著なわが国においては，日常生活を送 る上で久かすことのできない家電機器を高齢者が単独で容易 に操作できるよう配慮することは社会的要請でもある。ま た, ユーザーの高齢化傾向だけでなく, 近年の家電機器の多 機能化, 高機能化の進展の観点からも操作パネル部のユー ザーインタフェースデザインの重要性が高まってきている.

操作パネルのデザインは使用時の使いやすさを決定づける だけでなく，ユーザーが購買時点において分かりやすさ感や 製品の機能（この製品でどのようなことができるのか）を評 価する手がかりとしての役割も担っているためである.

筆者らは以下のような理由で, この操作パネルのユーザー インタフェースの良否には操作用語の分かりやすさが大きく 影響していると考えている.

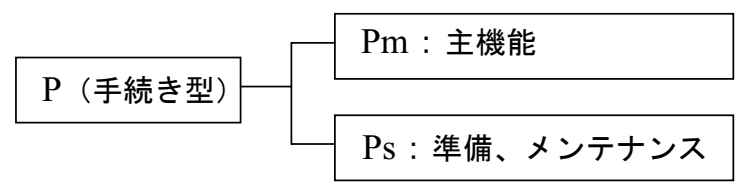

まず，操作パネルのデザイン開発プロセスから見ると最初 に対象機種の機能 (仕様) が決定され, その機能をキーワー ドに置き換えた上で，具体的なデザイン検討が開始される. 特にここで選定したキーワードは十分な検討がなされずにそ のまま操作用語として使用されるケースも少なくない．ま た，企業での製品やプロトタイプを用いたユーザビリテイ評 価に损いては，操作用語の分かりにくさに対する指摘は毎回 必ずといってよいほど観察されることが経験的に知られて いる. 以上のことから操作パネルのインタフェースデザイン の出発点となる操作用語の選定が, 最終的な操作パネルの分 かりやすさに大きな影響を及ぼすことが想定されるわけで ある.

そこで, 本研究では, これまで研究事例の少なかった家電 機器の操作パネルに使用される操作用語に着目し, その現状 分析と高齢ユーザーおよびその対照としての若年ユーザーに よる理解度評価に基づいて操作用語の分かりやすさを決定付

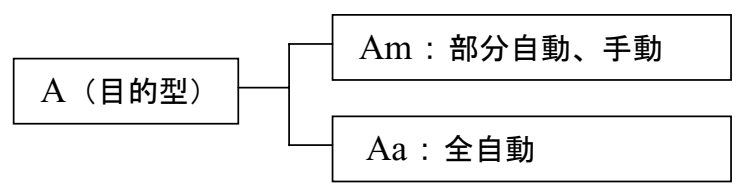

図1 改良版手続き型・目的型インタフェース分類法 
けている要因を探る.

なお, 本研究の最終的な目標はユニバーサルデザイン視点 からのわかりやすい操作用語選定のための指針策定にあ り, 今回の調査研究はこの目標に向け, わかりやすさに影響 を与えている用語属性抽出のための基礎調査研究と位置づ けている。

\section{2. 操作用語に着目したインタフェースの分類法}

\section{1 手続き型と目的型インタフェース}

ノーマン [1] はインタフェースデザインの基本のひとつ にユーザーのメンタルモデルへの適合を挙げている，家電機 器の操作に際して高齢ユーザーは過去, 自身が使用してきた 類似機器のインタフェースによってメンタルモデルが形成さ れていると考えられる。このためまず家電機器等コンシュー マ向けエレクトロニクス機器について, 操作用語に着目した インタフェースの歴史的変遷を大まかに捉えておく必要があ ると判断し, そのための基本的なインタフェースの分類方法 を検討することとした。

操作用語に関連したインタフェースの類型化の先行事例と して土屋 [2] の「手続き型インタフェースと目的型インタ フェースの分類方法」がある。これは操作方法がユーザーの 予備知識を前提にしているものか否か, あるいは機能表現に 間隔・比例尺度を用いているか, 名義尺度を用いているかを 判断基準とした分類方法である.

具体的に説明すると「手続き型インタフェース」とは操作 プロセスの中に比例尺度を用いた時間や温度, 強度などを設 定する手順の含まれるインタフェースタイプである。例え ば，電子レンジで「 $500 \mathrm{~W} ， 1$ 分」のように具体的数值によ り温度と時間を設定することで料理の仕上がり具合を調節し たり，洗濯機で洗濯物の量や質に対応して洗濯時間やすすぎ 回数を設定する方式等は比例尺度を用いた機能表現であり, これに該当する。

一方「目的型インタフェース」とはユーザーが「したい」 と意図したことを操作パネル上から選ぶインタフェースタ イプである，電子レンジの場合では，牛乳を温めたいという 意図が「のみもの」というボタンを押すことで, 洗濯機では 毛布を洗いたいという意図が「毛布」というボタンを押すこ とで，それぞれ実行に移されるようなインタフェースタイプ を言う。つまり電子レンジの例で言えば出力「500ワット」 で時間が「1分」と言う比例尺度による表現を「のみもの」 という名義尺度による表現に置き換えたインタフェースで ある。

ノーマン [1] はユーザーの操作行為を7段階理論で説明 している。これによれば操作行為は大きく実行段階と評価段

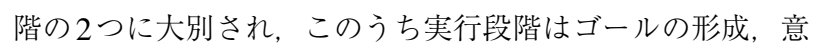
図の形成, 行為系列の設定, 行為の実行の4段階に細分化さ れるとしている．上記の「手続き型インタフェース」と「目 的型インタフェース」はこの理論に基づいて考察すると, 7 段階のうち主に実行段階の4段階への対応の仕方の違いによ
る区分であるということもできる.

洗濯機の例で言えば，「毛布を洗濯したい」というゴール が形成された後, 洗濯機を使用して洗濯をしようという意図 に変換される。 さらに操作パネルから「毛布」というメニュー を選定すればよいのだろうという行為系列の選定が行われ， 最後にメニューボタンを押して「毛布」メニューを選びスター トボタンを押し洗濯機が動き出すという手順を踏むことにな

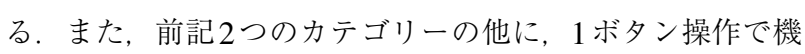
器が作動するタイプのインタフェースを「自動型インタ フェース」と名付け第3のカテゴリーとしている.

このように土屋の「手続き型インタフェースと目的型イン タフェースの分類方法」はユーザーの操作行為に着目した優 れた方法であるが，類型化の枠組みだけの提案にとどまって おり，実際の事例に適用した当てはまりの良さについての検 証はまだされていない.

\section{2 改良版手続き型・目的型インタフェース分類法}

まず，上記分類方法の家電機器への当てはまりの良さを検 証するため現行 (2005 年 10 月時点国内で販売中) の洗濯機, ジャー炊飯器, 電子レンジ（オーブンレンジ）の3種類の家 電機器の操作用語について分析を行った.

その結果, 多くの機能が手続き型と目的型, および自動型 に分類可能ではあるが，自動型の中でも，すべてを機械側に 委ねるのではなくユーザーが一定の目的を持って操作するこ とを前提としたタイプが存在し，これは「目的型」との区分 があいまいであること，また，どちらにも分類できない用語 も少なからず存在することが明らかになった。

新たなカテゴリーが必要な用語は, 洗濯機の例では「わた し流」や「予約」などユーザーの個別の目的に対応した部分 自動タイプ, また「槽洗浄」や「カビブロック」等機器運転 の準備・メンテナンスにかかわる用語等であった。

これらの用語を分類するためには比例尺度と名義尺度の違 いのみに着目した従来の手続き型・目的型インタフェース分 類法では分類が困難であると考えられるため, 間隔・比例尺 度, 名義尺度のみにこだわらない新たな分類基準を策定し, これを「改良版手続き型・目的型インタフェース分類法」と して新たに提案する（図1）.

新分類基準の特徵は次のとおりである.

1）手続き型と目的型の分類基準の主体を「間隔·比例尺度」 か「名義尺度」という表現上の基準から,「機器そのも のの操作手順」を示したものか, 「得られる結果」を示 したものかという内容的な基準に変更

また,ここでいう「得られる結果」とはユーザーがその 機器を使用する主な動機（ゴールの形成）であるその機 器が本来的に持つ機能に対応したものに限定し, それ以 外のものは機器を動作させるための手順の一部と見做 し，手続き型に含めた。

2）手続き型の下位に 2 種類のサブカテゴリーを設けた。 ひ とつ $(\mathrm{Pm})$ はその機器本来の主機能に関わるもの. も うひとつ（Ps）は機器を正常に稼動させるための準備や 
保守に関わるものである. 洗濯機の例で言えば前者は「洗 濯物を洗う」という機能に直接関連した「スタートルー 時停止」や「水量」などが該当する。一方後者は「槽洗浄」 や「点検」などである.

3）目的型下位に 2 種類のサブカテゴリーを設けた。ひとつ （Am）は手動運転に関わるものや，自動ではあるがユー ザーが特定のゴールを選択した上で操作する部分自動に 関わるものである，もうひとつはユーザーが特定のゴー ルを選択することなく機器に一任する方式の全自動に関 わるものである．洗濯機の例で言えば前者は，「毛布」や 「ナイト（主に夜間に使用する低騒音運転モード）」など, 一方後者は,「標準」や「おまかせ」などが該当する。 本分類基準により，前回の分類で収まりきれなかった「そ の他」のカテゴリーの用語についても手続き型か目的型のい ずれかに分類することが可能となった.

\section{3 新分類法に基づく主要家電機器操作用語の分類}

この分類方法に従えば，ほとんどの家電機器のユーザーイ ンタフェースが分類可能と考えられる。本研究ではまず 2007 年 6 月時点の国内主要家電機器 6 カテゴリー（洗濯乾燥 機, ジャー炊飯器, 電子レンジ, テレビ, クリーナー, ジャー ポット）の操作用語 428 語を抽出しこの分類法に基づき分類 を試みた。

分類結果を図 2 に示す。この結果全体の $73.1 \%$ を目的型イ ンタフェースが，またこのうち $96.5 \%$ を部分自動（Am）が それぞれ占めていることが明らかとなった。

本調査結果を踏まえ, ここ半世紀の家電機器を含むコン シューマエレクトロニクス機器のユーザーインタフェース を，歴史的に考察してみると，当初は単機能の製品がほとん どで，しかもそのインタフェースは手続き型 $(\mathrm{Pm})$ であっ たと考えられる。 その後, 全自動タイプの目的型 (Aa) が 登場し, さらに高機能化や個人のライフスタイルや嗜好の多 様化により, 目的型が細分化し, 部分自動タイプの目的型 (Am) が増加し現在に至っていると推測することができる.

さて, 本調査結果から, 今後操作パネル全体の用語の分か りやすさに影響する要因として，増加傾向にある部分自動夕 イプの目的型 $(\mathrm{Am})$ が第一に挙げられる. 2.1で述べたと おり手続き型（Pm, Ps）は比例尺度による定量的表現が主 体であるのに対し, 目的型（Aa, Am）は定性的表現が主体 である。このため手続き型に比べ表現にあいまいさが残る懸 念があることから, 次にこの目的型（Am）を中心に個々の 用語の属性とわかりやすさとの関連性を探ることとした.

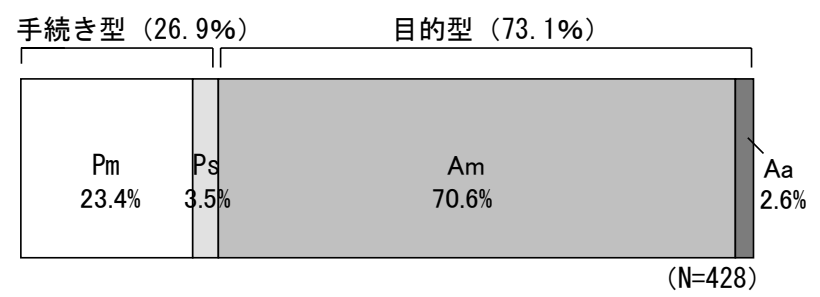

図2 手続き型・目的型インタフェース用語の出現率

\section{3. 修辞法や意味構造に着目した用語の分類}

\section{1 修辞法による分類}

はじめに，個々の用語のもつ内容や表現形態により梁く踏 み込んだ操作用語の分類視点として，修辞法に着目した。

清水 [3] らは, 修辞法の中の比喻の視点からピクトグラ ム (絵文字) の分類を試みている。 そもそもピクトグラムは 文字で表現可能な概念を抽象化された絵によって表現したも のであるため比喻的な側面を持つケースが多いと推測され る．例えば，空港などで使用される「レストラン」を示すピ クトグラムはナイフとフォークの抽象化された絵で示されて いるが, これはレストランそのものを絵にしたのではなく， レストランで使用される道具を示すことによりレストランの 存在を暗示した比喻表現である。

操作用語についても，この事例に倣い，比喻的側面からの 分類を試みた。

一般に比喻による表現形態は次の3種類に分類される [4].

1）提喻（シネクドキ）

集合の上下の包含関係を拡張した比喻形態である。例え ば「人はパンのみにて生きるにあらず」という文中の「パ ン」という単語は「パン」の持つ本来の意味を拡張し「食 糧」全体を指すものとして使われている.

2) 換喻（メトニミー）

対象物と隣接関係にあるものを用いた比喻形態である. 例えばグリム童話に登場する「赤頭巾」は，赤頭巾とい う衣類そのものを指すのではなく，それを身に着けてい る少女を指している。

3）暗喻（メタファー）

GUI（Graphical User Interface）におけるデスクトップ メタファーでよく知られた比喻形態である.

これは換喻とは異なり, 対象物とは隣接関係のないもの を用いた比喻形態である。例えば「君は僕の太陽だ」と いう文中の「君」という人間と「太陽」とは通常隣接関 係はないが，対象である「君」を話者にとってなくては ならない存在, 輝く存在として,「太陽」に見立てたも のである.

清水らの研究によれば，ピクトグラムの場合は比喻的表現 がピクトグラム全体に占める割合はかなり高く，しかも上記 レストランの例に見られるような換喻（メトニミー）による ものが多く見られることが分かっている.

これに対し, 操作用語の場合は比喻的表現よりも機能を直 接的に表現した例の方が多く観察された。 そこで，比喻以外 の分類方法も検討することとした。

\section{2 意味構造による分類}

橋本［5］らはIPAL（計算機用日本語基本形容詞辞書） 編集時に形容詞の連用用法について意味的な修飾関係に注目 して4つの分類を行っている.今回はこの分類法に着目し操 作用語に当てはめてみた。

IPALでは形容詞の連用用法 (動詞等を修飾する用法)を， 
その意味内容から, 以下の 4 カテゴリーに分類している.

1) 結果

形容詞が動作の結果を示しているもの.

例えば「石を丸く削る」(下線部が分類対象となる形容 詞を示す．以下同様）がこれに当たる.

操作用語での例として炊飯機の「おこげ」があげられる.

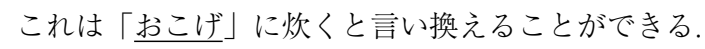

2）様態

形容詞が動作の「さま」をあらわしているもの.

例えば「つめたくあしらわれる」などがこれにあたる.

操作用語の例では, 洗濯機における「念入り」がこれに 相当する．この用語は「念入りに」洗うと言い換えが可 能である.

3）程度 $\cdot$ 量

形容詞が動詞の表す内容の程度や量を示しているもの

例えば「著しく変化する」など. 操作用語での例としては, 洗濯機の「たつぷり」があげられよう。これは「たつぷ 口（の量の洗濯物を）」洗うと言い換えることができる.

4) 心的態度

形容詞が主語の心的な状況を示しているもの

例えば「寂しく暮らしている」など．操作用語の例として は洗濯機の「拉いそぎ」があげられる。これはユーザーが 「おいそぎ」の状況下にあると言い換えることができる。

\section{3 その他の分類項目}

上記分類の他, 理解度に影響を及ぼす可能性のある分類方 法として下記 2 項目を採用した.

1）用語の共通性

各メーカー共通に使用され, 事実上の業界標準となって いるか, そうでないか. 当然のことながら, メーカー共 通用語はユーザーの認知度も他の用語に比べて高いと考 えられる。 今回は調査対象メーカー全てに共通している 用語を「標準用語」, 半数以上に共通している用語を「準 標準用語」と定義し分類を行った.

2) 外来語

高齢者は一般的に外来語（漢語を除く）に対する認知度 が低いと言われているため, 外来語が含まれているか否 かも分類基準とした。

\section{4. 分類調査結果}

\section{1 修辞法と意味構造による分類結果}

図3 図 4 に修辞法視点からの分類項目ごとの用語の出現 率を示す。

1）比喻による分類

比喻を用いた用語は全体の $7.5 \%$ に留まり, かつ暗喻の みが観察された。これはピクトグラムの多くに換喻が用 いられていることとは対照的な結果となった（図3）.

2）意味的修飾関係による分類

この分類が適用できた用語は全体の $18.9 \%$ であた. 4
つの小分類では,「様態」がもっとも多く見られた (図 4 ).

\section{2 その他の分類項目による分類結果}

図5〜図6にその他の分類項目ごとの用語の出現率を示す.

1）用語の共通性

共通用語の出現率は $12.6 \%$ であったが, 全メーカー共通 の事実上の標準用語に絞って目的型／手続型の分類を当 てはめてみるとそのほとんどが手続き型の用語であっ た。これは 2.3 章で述べたとおり，歴史的には当初手続 き型インタフェースが主流であり，そのときに使われ現 在まで生き残った用語が業界標準として定着したものと 考えられる。（図5)

2) 外来語

外来語は全体の $37.1 \%$ と，かなり高い数字を示した（図6）

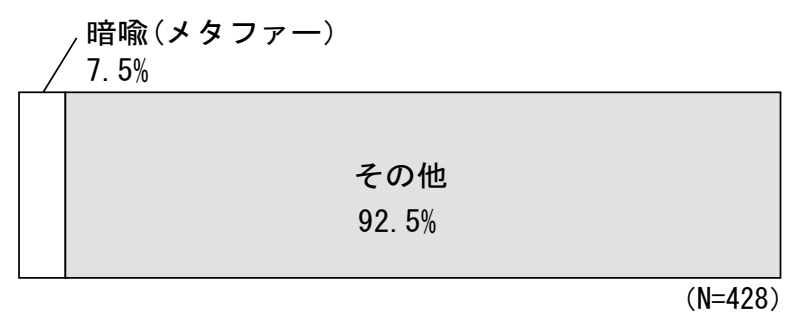

図3比喻表現の出現率

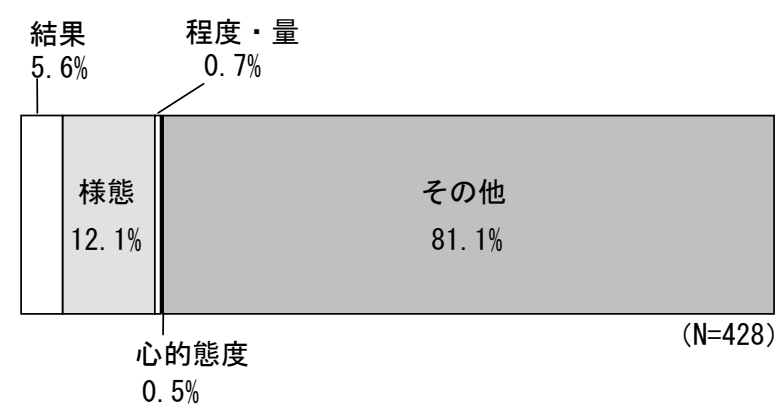

図4意味的修飾関係分類による出現率

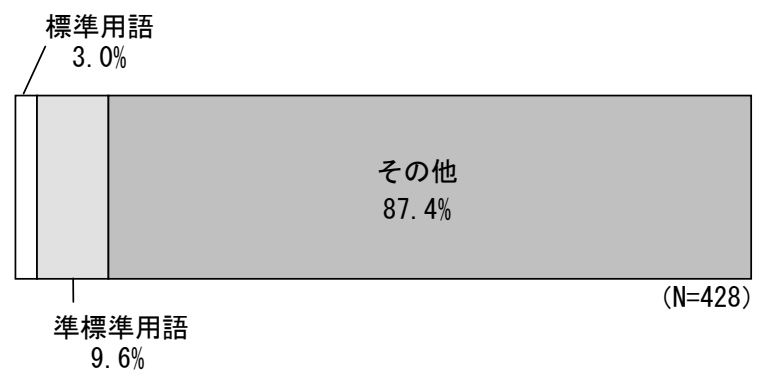

図5用語の共通性別出現率

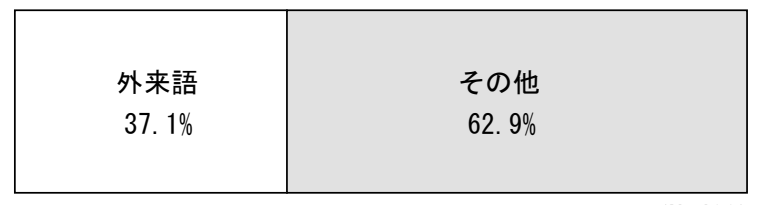

$(\mathrm{N}=428)$

図6 外来語の出現率 


\section{5. 高齢者による用語の理解度評価（第一次）}

\section{1 評 価 方 法}

次に, 分類した用語の中から, 家電機器の中でも日常生活 において使用頻度の高い洗濯機の目的型用語を中心に 53 語 を選定し，高齢者による理解度評価を実施した，主たる評価 対象は目的型用語であるが, 比較対象のため一部手続き型用 語も対象に含めた。

被験者は札幌市内在住の 65 歳以上の高龃者男女 22 名で, 平均年齢は男女それぞれ約 76 歳, 約 80 歳である.

評価方法は各用語の分かりやすさに関する 5 段階評価（理 解できない.やや理解しにくい.どちらともいえない・やや 理解できる・理解できる）を採用した.

尚, 事前に行った予備調査では, 用語の示す機能の意味も 提示したが，それによって用語自体を理解したものと判断す る被験者がほとんどであったため, 本調査では用語の意味は 示さず，意味が推測できるかどうかの程度について尋ねるこ ととした.

また，各用語の評価途中で質問内容を忘れる被験者が多 く観察されたため, 質問内容は各用語について繰り返し記 載した。

\section{2 評 価 結 果}

表 1 に評価結果を示す. 各分類属性別の評価結果は次のと おりである。

1）目的型, 手続型

当初の用語評価の目的が増加傾向にある目的型インタ フェース用語の理解度調査であったため, 評価対象は目 的型を多く取り入れたため, 比較することは適切ではな いが, 今回調査対象となった用語に限定すれば, 手続き 型の方がやや理解度が高い傾向が認められる。

2）比喻形態

比喻はすべてメタファーを用いたものであったが, 比喻 を用いない用語に比べ理解度が低い傾向にある。

3）意味的修飾関係

様態を用いた用語が多く観察されたが, 様態以外（「結 果」など）を用いた用語に比べて顕著な違いは認められ ない.

4）共通語

当然の結果ではあるが，限られたメーカーでのみ使用さ れている用語より, メーカー共通用語の方が理解度は高 い傾向にある.

5) 外来語

外来語を使用している用語とそれ以外の用語の間に顕著 な差異は見出せなかった。

\section{6. 高齢者による用語の理解度評価（第二次）}

\section{1 評 価 方 法}

第一次の評価では, 高齢者による用語評価の大まかな傾向
はつかめたものの, 評価結果と各属性との間に有意な関連は 見出すことができなかった。 また，アンケート調査時に高齢 者特有と思われるいくつかの反応（質問内容を忘れやすい, 甘い評価をしがち, 集中力の持続時間が短い等) が認められ たため, アンケート調査方法に改善を加えた第二次評価を実 施した，第一次評価との相違点は下記のとおりである.

1）被験者の負荷軽減のため, 評価対象用語を 10 語（第一次 理解度評価でのワースト 10）に絞った。

2）甘めの評価を検証するため，対照として若年被験者によ る評価も実施した。

3）高齢ユーザーと若年ユーザーのメンタルモデルの違いを 探る目的で, 被験者自身に各用語の意味内容にふさわし い用語表現を記入させた

\section{2 評 価 結 果}

表 2 に評価結果を示す.

評価カテゴリーのうち「理解できる」「やや理解できる」「高 理解群」,「どちらとも言えない」を「中間群」,「やや理解し にくい」「理解できない」を「低理解群」とし, また年齢層 を「高齢群 (65歳以上) 」, 「若年群 (40歳未満)」の 2 群に 分類し,「使用経験の有無」および 10 項目の用語の「理解度」 との関連について $\chi^{2}$ 検定を行った.

また, 用語の属性を, 「外来語あり」と「外来語なし」,「メ タファー」と「メタファー以外」, 意味的修飾関係の「様態」 と「様態以外」に分類, またそれぞれの理解度については, 「高齢群」と「若年群」および「全体」,「使用経験あり群」 と「使用経験なし群」別に paired t-testを用いて比較した。

尚, 目的型と手続き型, 用語の共通性等, 今回の 10 種類 の用語の中での分布の偏りの大きい属性については分析対象 から除いた。 その結果, $\chi^{2}$ 検定では, 年齢層と有意 $(\mathrm{p}<0.05)$ な関連が認められた項目は, 「棚乾燥」,「しわガード」であっ た. paired t-testの結果, 高齢群においては,「メタファーー メタファー以外」に打いて有意 $(\mathrm{p}<0.05)$ な差が認められた. また, 若年群においては, 「外来語あり一外来語なし」で有 意 $(\mathrm{p}<0.05)$ な差が認められた。 全体に揖いては,「メタファー ーメタファー以外」において有意 $(\mathrm{p}<0.05)$ な差が認められた.

\section{7. 考察とまとめ}

本研究では高齢者の日常生活をサポートする家電機器の ユーザーインタフェース向上を目的に，その実現に向け大き な影響力を持つ操作用語の理解度調査分析を行った.

まずはじめに, 高齢者のメンタルモデルに配慮し, 用語イ ンタフェースの歴史的変遷を把握するための構造分類を試み た.ここでは土屋の提唱した手続き型・目的型インタフェー スの分類方法を手がかりに家電機器のユーザーインフェース にも当てはまりのよい分類法を検討し, 新たに機器の本来機 能か付随機能か, 選択型自動か全自動かという下位カテゴ リーを含む改良手続き型・目的型インタフェース分類方法を 立案した。 
表1 高齢者による用語の理解度評価結果（一次評価）

\begin{tabular}{|c|c|c|c|c|c|c|c|c|}
\hline 番号 & 用語 & 共通性 & 目的/手続型 & 小分類 & 外来語 & 比喻形態 & 修飾形態 & 平均評点 \\
\hline 1 & スタート/一時停止 & $\bigcirc$ & 手続 & $\mathrm{Pm}$ & $\bigcirc$ & $*$ & $*$ & $4.70 \pm 0.73$ \\
\hline 2 & 乃ろ水 & $\bigcirc$ & 目的 & $\mathrm{Am}$ & $*$ & $*$ & $*$ & $4.35 \pm 1.18$ \\
\hline 3 & 予約 & $\bigcirc$ & 目的 & $\mathrm{Am}$ & $*$ & x夕 & 様 & $3.80 \pm 1.74$ \\
\hline 4 & 水量 & $\times$ & 手続 & $\mathrm{Pm}$ & $*$ & $*$ & $*$ & $4.25 \pm 1.37$ \\
\hline 5 & 洗い & $\bigcirc$ & 目的 & $\mathrm{Am}$ & $*$ & $*$ & $*$ & $4.70 \pm 0.57$ \\
\hline 6 & 洗濯 & $\bigcirc$ & 目的 & $\mathrm{Am}$ & $*$ & $*$ & $*$ & $4.45 \pm 1.00$ \\
\hline 7 & すすぎ & $\bigcirc$ & 目的 & $\mathrm{Am}$ & $*$ & $*$ & $*$ & $4.60 \pm 0.75$ \\
\hline 8 & 脱水 & $\bigcirc$ & 目的 & $\mathrm{Am}$ & $*$ & $*$ & $*$ & $4.71 \pm 0.56$ \\
\hline 9 & 乾燥 & $\bigcirc$ & 目的 & $\mathrm{Am}$ & $*$ & $*$ & * & $4.65 \pm 0.67$ \\
\hline 10 & 洗濯コ一ス & $\times$ & 目的 & $\mathrm{Am}$ & 0 & $*$ & 様 & $4.29 \pm 1.19$ \\
\hline 11 & 洗·乾コ一ス & $\times$ & 目的 & Am & $\bigcirc$ & $*$ & 様 & $4.25 \pm 1.12$ \\
\hline 12 & 乾燥コ一ス & $\triangle$ & 目的 & Am & 0 & $*$ & 様 & $4.58 \pm 0.84$ \\
\hline 13 & 槽手入れ & $\times$ & 手続 & $\mathrm{PS}$ & $*$ & $*$ & $*$ & $3.65 \pm 1.50$ \\
\hline 14 & 槽乾燥 & $\bigcirc$ & 手続 & Ps & $*$ & $*$ & $*$ & $3.84 \pm 1.43$ \\
\hline 15 & 槽洗浄 & $\bigcirc$ & 手続 & Ps & $*$ & $*$ & $*$ & $3.44 \pm 1.58$ \\
\hline 16 & 棚乾燥 & $\bigcirc$ & 目的 & Am & $*$ & $*$ & 様 & $2.59 \pm 1.70$ \\
\hline 17 & 毛布 & $\bigcirc$ & 目的 & $\mathrm{Am}$ & $*$ & $*$ & $*$ & $3.83 \pm 1.58$ \\
\hline 18 & 除菌脱臭 & $\triangle$ & 目的 & Am & $*$ & $*$ & $*$ & $4.22 \pm 1.26$ \\
\hline 19 & スピーディー & $x$ & 目的 & $\mathrm{Am}$ & 0 & $*$ & $*$ & $3.84 \pm 1.61$ \\
\hline 20 & 念入り & $\bigcirc$ & 目的 & $\mathrm{Am}$ & $*$ & $*$ & 様 & $4.05 \pm 1.43$ \\
\hline 21 & メモリー & $\triangle$ & 目的 & $\mathrm{Am}$ & 0 & x夕 & $*$ & $3.35 \pm 1.76$ \\
\hline 22 & ドライ & $\bigcirc$ & 目的 & $\mathrm{Am}$ & 0 & $*$ & $*$ & $4.15 \pm 1.35$ \\
\hline 23 & エアウォッシュ & $\times$ & 目的 & $\mathrm{Am}$ & 0 & メ夕 & $*$ & $3.95 \pm 1.39$ \\
\hline 24 & スチーム乾燥 & $\times$ & 目的 & $\mathrm{Am}$ & $\bigcirc$ & $*$ & $*$ & $4.10 \pm 1.12$ \\
\hline 25 & スチーム洗浄 & $x$ & 手続 & $\mathrm{Am}$ & 0 & $*$ & $*$ & $3.56 \pm 1.62$ \\
\hline 26 & 水リサイクル & $x$ & 目的 & $\mathrm{Am}$ & 0 & $*$ & 様 & $4.26 \pm 1.24$ \\
\hline 27 & 標準 & 0 & 目的 & $\mathrm{Aa}$ & $*$ & $*$ & 様 & $4.32 \pm 1.36$ \\
\hline 28 & おいそぎ & 0 & 目的 & $\mathrm{Am}$ & $*$ & $*$ & 心 & $4.00 \pm 1.45$ \\
\hline 29 & 洗剂ゼロ & $\times$ & 目的 & $\mathrm{Am}$ & $\bigcirc$ & $*$ & 様 & $4.00 \pm 1.38$ \\
\hline 30 & 温水コ一ス & $x$ & 目的 & $\mathrm{Am}$ & 0 & $*$ & $*$ & $4.20 \pm 1.36$ \\
\hline 31 & おまかせ & $\times$ & 目的 & $\mathrm{Aa}$ & $*$ & x夕 & 様 & $4.00 \pm 1.45$ \\
\hline 32 & わたし流 & $x$ & 目的 & $\mathrm{Am}$ & $*$ & x夕 & 様 & $3.27 \pm 1.83$ \\
\hline 33 & ナイト & $\times$ & 目的 & $\mathrm{Am}$ & $\bigcirc$ & x夕 & $*$ & $2.91 \pm 1.85$ \\
\hline 34 & 柔らかプラス & $\times$ & 目的 & $\mathrm{Am}$ & $\bigcirc$ & $*$ & 結 & $3.45 \pm 1.57$ \\
\hline 35 & おうちクリーニング & $\times$ & 目的 & $\mathrm{Am}$ & O & メ夕 & $*$ & $2.55 \pm 1.47$ \\
\hline 36 & タイマー（時間設定） & $\times$ & 手続 & $\mathrm{Pm}$ & $\bigcirc$ & $*$ & $*$ & $4.05 \pm 1.32$ \\
\hline 37 & 水位 & $\triangle$ & 手続 & $\mathrm{Pm}$ & $*$ & $*$ & $*$ & $4.18 \pm 1.33$ \\
\hline 38 & チャイルドロック & $\times$ & 手続 & Ps & $\bigcirc$ & $*$ & $*$ & $3.40 \pm 1.47$ \\
\hline 39 & 音声 & $\triangle$ & 手続 & $\mathrm{Ps}$ & $*$ & $*$ & $*$ & $3.65 \pm 1.63$ \\
\hline 40 & ホット高洗浄 & $\times$ & 目的 & $\mathrm{Am}$ & $\bigcirc$ & $*$ & 様 & $3.20 \pm 1.70$ \\
\hline 41 & お湯取 & $\times$ & 目的 & $\mathrm{Am}$ & $*$ & $*$ & 様 & $2.90 \pm 1.58$ \\
\hline 42 & 手造り & $\times$ & 目的 & $\mathrm{Am}$ & $*$ & x夕 & 様 & $2.77 \pm 1.63$ \\
\hline 43 & しわガード & $\times$ & 目的 & $\mathrm{Am}$ & 0 & $*$ & $*$ & $3.00 \pm 1.59$ \\
\hline 44 & これっきりボタン & $x$ & 目的 & $\mathrm{Aa}$ & 0 & x夕 & $*$ & $2.80 \pm 1.54$ \\
\hline 45 & 洗·乾切換 & $\triangle$ & 目的 & $\mathrm{Am}$ & $*$ & $*$ & $*$ & $4.30 \pm 1.03$ \\
\hline 46 & 電源/入·切 & $\bigcirc$ & 手続 & $\mathrm{Pm}$ & $*$ & $*$ & $*$ & $4.62 \pm 0.87$ \\
\hline 47 & 温水 & $x$ & 目的 & $\mathrm{Am}$ & $*$ & $*$ & $*$ & $4.62 \pm 0.74$ \\
\hline 48 & つナおき & 0 & 目的 & $\mathrm{Am}$ & $*$ & $*$ & 様 & $4.57 \pm 0.75$ \\
\hline 49 & ロック解除 & $\times$ & 手続 & $\mathrm{Ps}$ & 0 & $*$ & $*$ & $3.75 \pm 1.65$ \\
\hline 50 & 大物 & $x$ & 目的 & $\mathrm{Am}$ & $*$ & x夕 & $*$ & $4.00 \pm 1.30$ \\
\hline 51 & 室内干し & $x$ & 目的 & $\mathrm{Am}$ & $*$ & $*$ & 結 & $4.30 \pm 1.13$ \\
\hline 52 & ソフト乾燥 & $x$ & 目的 & $\mathrm{Am}$ & 0 & $*$ & 結 & $4.15 \pm 1.27$ \\
\hline 53 & わが家流 & $\times$ & 目的 & Am & $*$ & x夕 & 様 & $3.65 \pm 1.46$ \\
\hline
\end{tabular}


表2 高齢者および若年者による用語の理解度評価結果（二次評価）

被験者の属性

\begin{tabular}{llll}
\hline 属性 & & $\mathrm{N}(\%)$ & $\mathrm{Mean} \pm \mathrm{SD}$ \\
\hline 年代別 & 40歳未満 & $31(47.7)$ & $25.90 \pm 6.52$ \\
& 65歳以上 & $34(52.3)$ & $77.47 \pm 8.29$ \\
\hline 性別 & 男性 & $7(10.8)$ & \\
& 女性 & $58(89.2)$ & \\
\hline 洗濯機使用経験 & あり & $61(93.8)$ & \\
& なし & $4(6.2)$ & \\
\hline
\end{tabular}

年齢層別理解度

$(\mathrm{N}=65)$

\begin{tabular}{|c|c|c|c|c|c|c|c|}
\hline \multirow[b]{2}{*}{ 用語 } & & & & \multicolumn{3}{|c|}{ 用語の理解度別人数(\%) } & \\
\hline & & & & 高理解群 & 中間群 & 低理解群 & \\
\hline 棚乾燥 & $(n=64)$ & $\begin{array}{l}\text { 若年層(群) } \\
\text { 高齢層(群) }\end{array}$ & $\begin{array}{l}(n=31) \\
(n=33)\end{array}$ & $\begin{array}{ll}11 & (35.5) \\
19 & (57.6) \\
\end{array}$ & $\begin{array}{rr}6 & (19.4) \\
1 & (3.0) \\
\end{array}$ & $\begin{array}{ll}14 & (45.1) \\
13 & (39.4) \\
\end{array}$ & $*$ \\
\hline メモリー & $(n=63)$ & $\begin{array}{l}\text { 若年層(群) } \\
\text { 高齢層(群) }\end{array}$ & $\begin{array}{l}(n=31) \\
(n=32)\end{array}$ & $\begin{array}{ll}19 & (61.3) \\
21 & (65.6) \\
\end{array}$ & $\begin{array}{ll}5 & (16.1) \\
4 & (12.5)\end{array}$ & $\begin{array}{ll}7 & (22.6) \\
7 & (21.9) \\
\end{array}$ & \\
\hline わたし流 & $(n=63)$ & $\begin{array}{l}\text { 若年層(群) } \\
\text { 高齢層(群) }\end{array}$ & $\begin{array}{l}(n=31) \\
(n=32)\end{array}$ & $\begin{array}{ll}23 & (74.2) \\
18 & (56.2) \\
\end{array}$ & $\begin{array}{ll}3 & (9.7) \\
3 & (9.4) \\
\end{array}$ & $\begin{aligned} 5 & (16.1) \\
11 & (34.4)\end{aligned}$ & \\
\hline ナイト & $(n=61)$ & $\begin{array}{l}\text { 若年層(群) } \\
\text { 高齢層(群) }\end{array}$ & $\begin{array}{l}(n=30) \\
(n=31)\end{array}$ & $\begin{array}{ll}24 & (80.0) \\
18 & (58.1) \\
\end{array}$ & $\begin{array}{lr}2 & (6.7) \\
4 & (12.9) \\
\end{array}$ & $\begin{array}{ll}4 & (13.3) \\
9 & (29.0)\end{array}$ & \\
\hline $\begin{array}{l}\text { おうち } \\
\text { クリーニング }\end{array}$ & $(n=60)$ & $\begin{array}{l}\text { 若年層(群) } \\
\text { 高齢層(群) }\end{array}$ & $\begin{array}{l}(n=29) \\
(n=31)\end{array}$ & $\begin{array}{ll}16 & (55.2) \\
15 & (48.4) \\
\end{array}$ & $\begin{array}{rr}7 & (24.1) \\
3 & (9.7) \\
\end{array}$ & $\begin{array}{rr}6 & (20.7) \\
13 & (41.9) \\
\end{array}$ & \\
\hline ホット高洗浄 & $(n=62)$ & $\begin{array}{l}\text { 若年層(群) } \\
\text { 高齢層(群) }\end{array}$ & $\begin{array}{l}(n=29) \\
(n=33)\end{array}$ & $\begin{array}{ll}11 & (37.9) \\
14 & (42.4) \\
\end{array}$ & $\begin{aligned} 10 & (34.5) \\
5 & (15.2)\end{aligned}$ & $\begin{aligned} & 8(27.6) \\
& 14(42.4) \\
&\end{aligned}$ & \\
\hline お湯取り & $(n=62)$ & $\begin{array}{l}\text { 若年層(群) } \\
\text { 高齢層(群) }\end{array}$ & $\begin{array}{l}(n=30) \\
(n=32)\end{array}$ & $\begin{array}{ll}21 & (70.0) \\
23 & (71.8) \\
\end{array}$ & $\begin{array}{rr}5 & (16.7) \\
3 & (9.4) \\
\end{array}$ & $\begin{array}{ll}4 & (13.3) \\
6 & (18.8) \\
\end{array}$ & \\
\hline 手造り & $(n=61)$ & $\begin{array}{l}\text { 若年層(群) } \\
\text { 高齢層(群) }\end{array}$ & $\begin{array}{l}(n=31) \\
(n=30)\end{array}$ & $\begin{aligned} 8 & (25.8) \\
14 & (46.7)\end{aligned}$ & $\begin{array}{lr}4 & (12.9) \\
2 & (6.6)\end{array}$ & $\begin{array}{ll}19 & (61.3) \\
14 & (46.7)\end{array}$ & \\
\hline しわガード & $(n=56)$ & $\begin{array}{l}\text { 若年層(群) } \\
\text { 高齢層(群) }\end{array}$ & $\begin{array}{l}(n=31) \\
(n=25)\end{array}$ & $\begin{array}{ll}25 & (80.6) \\
16 & (64.0) \\
\end{array}$ & $\begin{array}{rr}4 & (12.9) \\
1 & (4.0) \\
\end{array}$ & $\begin{array}{lr}2 & (6.5) \\
8 & (32.0) \\
\end{array}$ & * \\
\hline $\begin{array}{l}\text { これっきり } \\
\text { ボタン }\end{array}$ & $(n=56)$ & $\begin{array}{l}\text { 若年層(群) } \\
\text { 高齢層(群) }\end{array}$ & $\begin{array}{l}(n=30) \\
(n=26)\end{array}$ & $\begin{array}{ll}14 & (46.7) \\
14 & (53.8)\end{array}$ & $\begin{array}{lr}6 & (20.0) \\
2 & (7.7)\end{array}$ & $\begin{array}{ll}10(33.3) \\
10(38.5)\end{array}$ & \\
\hline
\end{tabular}

$* \mathrm{p}<0.05$

インタフェース用語の属性別理解度平均値の比較（若年層・高齢層・全体）

\begin{tabular}{|c|c|c|c|c|c|c|c|}
\hline & & 若年層(群) & & 高齢層(群) & & 全 体 & \\
\hline 外来語 & $\begin{array}{l}\text { あり } \\
\text { なし }\end{array}$ & $\begin{array}{l}3.70 \pm 0.14 \\
31.5 \pm 0.13\end{array}$ & * & $\begin{array}{l}3.20 \pm 0.23 \\
3.16 \pm 0.22\end{array}$ & & $\begin{array}{l}3.46 \pm 0.14 \\
3.15 \pm 0.12\end{array}$ & \\
\hline 比䜽 & $\begin{array}{l}\text { メタファー } \\
\text { メタファー以外 }\end{array}$ & $\begin{array}{l}3.07 \pm 0.26 \\
3.23 \pm 0.23\end{array}$ & & $\begin{array}{l}3.35 \pm 0.14 \\
3.67 \pm 0.14\end{array}$ & $*$ & $\begin{array}{l}3.22 \pm 0.14 \\
3.46 \pm 0.13\end{array}$ & $*$ \\
\hline 修飾関係 & $\begin{array}{l}\text { 様態 } \\
\text { 様態以外 }\end{array}$ & $\begin{array}{l}3.16 \pm 0.26 \\
3.14 \pm 0.22\end{array}$ & & $\begin{array}{l}3.32 \pm 0.15 \\
3.63 \pm 0.15\end{array}$ & & $\begin{array}{l}3.24 \pm 0.14 \\
3.40 \pm 0.13\end{array}$ & \\
\hline
\end{tabular}

$* \mathrm{p}<0.05$

本分類方法に基づき, 主要な家電機器の操作用語の分類を 試みたところ, 最近のインタフェースは大半が手続き型から 目的型に移行していることが明らかになった。また目的型の 用語の中には高齢者にはわかりにくいと考えられる定性的な 表現の用語が多く存在することが推測された.

次にこの目的型インタフェースを対象に用語の持つ修辞法 的側面に着目した，比喻的な表現形態，および意味的修飾関 係による用語分類, さらに用語の共通性, 外来語の有無等, さらに踏み込んだ多面的な分類を試みた。

分類の結果, 比喻視点ではメトニミーの利用が顕著なピク トグラムの場合と異なり, 操作用語の場合メタファーの利用
が主体となることが判明した。また意味的修飾関係ではほ とんどが様態を採用していることが分かった.

次いで, 高齢被験者および対照としての若年被験者を対象 に2 次に渡る各用語の理解度評価を行い, 前述の用語分類と 照合し，理解度に影響のある用語の属性抽出を行った。この 結果, 用語の理解度に影響する用語属性として以下の項目の 影響が示唆された。

1）過去の手続き型インタフェース時代から継続して使用さ れている事実上の業界標準となっている手続き型インタ フェース用語は修辞法視点等それ以外の属性にかかわら ず他の用語より理解度が高い傾向にある. 
2）メタファーを使用して作られた目的型インタフェース用 語は他の用語より顕著に理解度が低い傾向にある。

3）外来語の使用は, 若年層には理解度を高める方向に, 逆 に高齢層には理解度を阻害する傾向が認められた。

4）新機能を表す用語（棚乾燥, しわガード等）は全般に高 齢層には理解度が低い傾向にある．当然のことながら， 新機能そのものに対する知識が不足していることも原因 として考えられるが, 一方で新機能についてはメーカー 側が他社との差別化を狙ったと思われる一般的でない表 現（メタファーの多用等）を用いることも原因のひとつ と考えられる.

以上の結果より，高齢者にとって分かりやすい操作用語を 創出・選択するためには, 業界内での用語の共通化の一層の 推進, 目的型インタフェース用語に比喻（メタファー）を用 いる場合や外来語を使用する場合は高齢者のメンタルモデル に配慮し, それが直感的に理解可能なものかの十分な事前検 証が必要であることが示唆された.

今後は, 小児も含む若年層を対象とした評価検証を実施 し，それぞれの世代間のメンタルモデルの違いを明らかに し，広範なユーザー層を想定した操作用語のユニバーサルデ ザイン化のための基礎デー夕を整備したいと考える.

\section{謝 辞}

本研究実施にあたっては武蔵工業大学清水由美子准教授に 貴重なご助言をいただいた。 また, 札幌市中央区桑園町内会 各位, 当別町弥生さくら館各位, 札幌市立高等専門学校およ び札幌市立大学学生・職員各位には用語アンケートにご協力 をいただいた。ここに厚く御礼申し上げる。

\section{参 考 文 献}

［1］D. A.ノーマン, 野島久雄（訳）：誰のためのデザイン：新 曜社（1990）

[2] 土屋雅人：目的型ユーザインタフェースの設計方法論の研 究; 千葉大学博士論文 (2001)

［3］清水由美子：概念伝達に用いられる絵の理解と意味処理を めぐる実証的研究; 東京工業大学博士論文 (2007)

[4] 野内良三：レトリックと認識; 日本放送出版協会（2000）

[5] 橋本三奈子, 青山文啓: 形容詞の三つの方法; 計量国語学 Vol.18, No.5, pp.201-214 (1992)

[6] 金井良行：製品インタフェース機能の定式化の研究と提 案; 広島国際大学卒業研究論文 (2006)

[7] 金井良行, 井上勝雄, 酒井正幸：インタフェース機能表記 の調査分析; 日本人間工学会中国 - 四国支部第 39 回大会 報文集, pp.2-3（2006）

［8］井上勝雄, 酒井正幸, 金井良行 : コンテクストインタフェー スの提案; 日本感性工学会 第8回大会報文集, p.347(2006)

[9] 酒井正幸, 多賀昌江, 照井レナ, 井上勝雄 : 家電機器操作
用語の修辞法的属性分析に基づくわかりやすさの評価；日 本感性工学会 感性フォーラム札幌 2008 講演論文集, p.15 (2008)

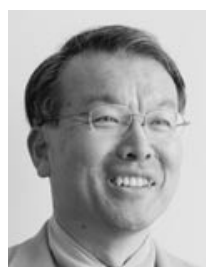

\section{酒井 正幸 (正会員)}

1973 年千葉大学工学部工業意匠学科卒業. 同年三菱電機（株）入社. 2001 年同社情報 技術総合研究所計画部長, その後同社宣伝部 次長を歴任し, 2004 年より同社デザイン研 究所ホームシステムデザイン部長を経て,

2006 年より札幌市立大学デザイン学科教授, 現在に至る. 認定 人間工学専門家. ユニバーサルデザインおよびユーザビリティ 評価を含むインタフェースデザイン研究に従事. 1988 年ファク シミリデザインでドイツif 賞審査員特別賞受賞. 日本感性工学 会, 日本デザイン学会, 日本人間工学会などの各会員.

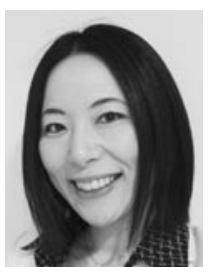

\section{照井 レナ（非会員）}

2004 年北海道医療大学大学院看護福祉学研 究科地域看護学講座修了. 11 年におよぶ自治 体保健師の経験をもとに, 大学院修了後は訪 問看護ステーションや精神科の救急および ディケアで活動. 現在, 札幌市立大学看護学 部在宅看護学領域助教. インタフェースデザインのユニバーサ ルデザインおよびユーザビリティの評価研究では, 主に高齢ユー ザーための調査票作成やフィールド開拓，統計解析を担当．日 本人間工学会の会員.

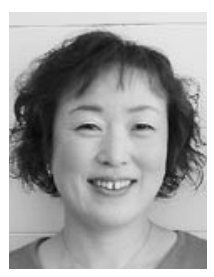

多賀 昌江 (非会員)

2005 年札幌医科大学大学院保健医療学研究 科修了 (看護学修士), 助産師。通算 11 年間 助産師として勤務し, NICUと周産期看護に 携わる。2005 年より札幌市立大学看護学部 母性看護学領域の教員として就任し, 出産と 育児における医療人類学研究のほか, 看護とデザイン分野の融 合研究を遂行中. 日本看護科学学会, 日本文化人類学会, 日本 人間工学会などの各会員.

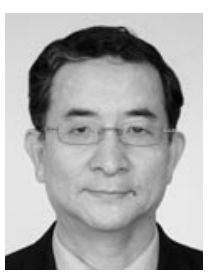

\section{井上 勝雄 (正会員)}

1978 年千葉大学大学院工学研究科修了. 同 年三菱電機（株）に入社. 2000 年同社デザ イン研究所インタフェースデザイン部長を経 て, 2002 年より広島国際大学感性デザイン 学科教授, 現在に至る。博士 (工学), 認定 人間工学専門家. 感性工学およびデザイン評価, ラフ集合を用 いたデザイン設計論, インタフェースデザインに関する研究に 従事. 1996 年日本デザイン学会研究奨励賞受賞, 2004 年 . 2005 年日本感性工学会出版賞受賞, 2005 年日本知能情報ファジ イ学会著述賞受賞. 日本感性工学会, 日本デザイン学会, 日本 知能情報ファジイ学会, 日本人間工学会などの各会員. 